\title{
Pengaruh Aplikasi “Mommy Nifas" terhadap Peningkatan Pengetahuan dan Keterampilan Ibu
}

\section{Effect of Mommy Nifas Application to Increase Knowledge and Skill of Mother}

\author{
Nopi Anggista Putri ${ }^{1}$, Dany Hilmanto ${ }^{2}$, Zulvayanti $^{3}$ \\ Fakultas Kedokteran, Universitas Padjadjaran, Indonesia
}

\section{ARTICLE INFO}

\section{Article history}

Received date

06 Nov 2020

Revised date

16 Feb 2021

Accepted date

08 Apr 2021

\section{Keywords:}

Applications;

Knowledge;

Postpartum;

Skill.

\section{Kata kunci:}

Aplikasi;

Pengetahuan;

Nifas;

Keterampilan.

\begin{abstract}
ABSTRAK
Complications of the puerperium are a contributing factor to the high maternal mortality rate (MMR). One effort to reduce the MMR is to increase the knowledge and skills of mothers regarding postpartum care. This study aims to analyze the effect of using an application that contains information about postpartum care to increase the knowledge and skills of mothers. This study uses a quasi-experimental design with a pre-posttest with a control group design. The subjects of the study were postpartum mothers in the work area of Gadingrejo Public Health Center from September to October 2019 with 60 respondents, consisting of 30 respondents from the treatment group and another 30 from the control group using consecutive sampling techniques. The intervention group is mothers who get the mommy nifas application and the control group is mothers who don't get application data analysis using the chi-square test. The results showed an increase in knowledge after giving higher mommy nifas application which is 71,5 (pre-test) to 93 (post-test) with a value of $\mathrm{p}$-value $<0,05$. Skills improved from 50 (pre-test) to 70,5 (posttest) with a p-value $<0,05$. The percentage increase in knowledge after using the application is by $17 \%$ and skills by $40 \%$ with a value of $p$-value $<0,05$. The conclusion of this study is that there is an effect of increasing skills and increasing the percentage of mothers' knowledge after using mommy nifas applications.
\end{abstract}

Komplikasi masa nifas merupakan faktor penyebab tingginya Angka Kematian Ibu (AKI). Salah satu upaya menurunkan AKI adalah meningkatkan pengetahuan dan keterampilan ibu mengenai perawatan masa nifas. Penelitian ini bertujuan untuk menganalisis pengaruh penggunaan aplikasi yang berisikan informasi mengenai perawatan masa nifas terhadap peningkatan pengetahuan dan keterampilan ibu. Penelitian ini menggunakan rancangan quasi experiment dengan pre-posttest with control group design. Subjek penelitian yaitu ibu nifas di wilayah kerja peskesmas gadingrejo pada bulan september sampai dengan oktober tahun 2019 sebanyak 60 responden, yaitu 30 responden kelompok perlakuan dan 30 kelompok kontrol dengan teknik consecutive sampling. Kelompok intervensi yaitu ibu yang mendapatkan aplikasi mommy nifas dan kelompok kontrol yaitu ibu yang tidak mendapatkan aplikasi mommy nifas Analisis data menggunakan uji chi square. Hasil penelitian menunjukkan peningkatan pengetahuan sesudah diberikan aplikasi mommy nifas lebih tinggi yaitu 71,5 (pre-test) menjadi 93 (post-test) dengan nilai $p$-value $<0,05$. Keterampilan meningkat dari 50 (pre-test) menjadi 70,5 (post-test) dengan nilai $p$-value $<0,05$. Persentase kenaikan pengetahuan setelah menggunakan aplikasi sebesar $17 \%$ dan keterampilan sebesar $40 \%$ dengan nilai $p$ value $<0,05$. Terdapat pengaruh peningkatan keterampilan dan peningkatan persentase pengetahuan ibu setelah menggunakan aplikasi mommy nifas.

Corresponding Author:

Nopi Anggista Putri

Fakultas Kedokteran, Universitas Padjadjaran, Indonesia

Email: nopianggista@gmail.com

\section{PENDAHULUAN}

Salah satu faktor penyebab kematian ibu adalah komplikasi pada masa nifas. komplikasi masa nifas yang paling tinggi angka kejadiannya adalah perdarahan dan infeksi.Pada masa nifas komplikasi dan masalah kesehatan yang sering terjadi adalah ketidaknyamanan pada payudara 
(82\%), gatal pada bagian perut $(40 \%)$, gatal pada bagian perineum $(15 \%)$, keputihan $(15 \%)$, dan kelelahan (78\%). Hal ini dapat diatasi dengan memberikan pengetahuan yang cukup pada ibu tentang perawatan diri pada masa nifas (Rachmawati, et al., 2001).

Masa nifas adalah masa setelah partus selesai sampai pulihnya kembali alat-alat kandungan seperti sebelum hamil, lamanya masa ini sekitar 6-8 minggu (Dewi, 2020). Periode ini merupakan masa rawan, karena banyak terjadi kematian ibu dan bayi. Pada masa ini wanita akan mengalami perubahan yang berbeda baik fisik, mental yang dapat mengganggu kegiatan mereka sehari-hari. Berbagai macam komplikasi juga dapat terjadi seperti fisik, mental, dan masalah emosional yang meliputi kelelahan, kebutuhan seksual yang menurun, hemoroid, konstipasi, masalah menyusui, cemas, stres, depresi, gangguan tidur, perdarahan, kesulitan berkemih. Oleh karena itu pelayanan berkualitas dibutuhkan untuk menangani keadaan ini.

Perawatan masa nifas merupakan salah satu komponen penting dalam pencegahan komplikasi pada ibu serta meningkatkan kesehatan bagi ibu maupun bayi baru lahir.Pada kenyataannya masih terdapat $58,5 \%$, ibu memiliki pengetahuan yang kurang dan memiliki praktik yang buruk $71 \%$ mengenai praktik perawatan nifas.Informasi yang kurang mengenai perawatan nifas disebabkan kurangnya pemberian informasi nifas pada saat pemeriksaan kehamilan dan singkatnya waktu tinggal ibu dan bayi setelah bersalin di fasilitas kesehatan. Hal ini menunjukkan bahwa wanita yang menerima perawatan nifas lebih rendah dari wanita yang menerima perawatan pada masa kehamilan (Sagita, 2015).

Pengetahuan ibu yang kurang tentang perawatan masa nifas, membuat ibu tidak cukup terampil untuk beradaptasi dengan kondisi saat ini dan kurang percaya diri untuk merawat diri sendiri dan bayi mereka.Sekitar $40 \%$ ibu mengalami komplikasi pasca persalinan, di antaranya $15 \%$ menghadapi konsekuensi jangka panjang yang serius. Komplikasi ini tidak hanya memengaruhi kesehatan ibu, tetapi juga memengaruhi status kesehatan bayi, dan mungkin berakhir dengan kematian (Wieger, 2006).

Salah satu bentuk dukungan pemerintah dalam mengurangi AKI yaitu bidan dalam memberikan asuhan pada masa nifas berpedoman pada Peraturan Menteri Kesehatan Nomor 97 Tahun 2014, yang terdiri dari pelayanan kesehatan masa sesudah melahirkan meliputi: Pelayanan kesehatan bagi ibu dan pelayanan kesehatan bayi baru lahir. Pelayanan kesehatan bagi ibu paling sedikit 3 (tiga) kali selama masa nifas (Kemenkes RI, 2014).

Selain itu, pemberian informasi kesehatan dilakukan juga oleh tenaga kesehatan khususnya bidan melalui pemanfaatan buku Kesehatan Ibu dan Anak (KIA) pada saat pemberian pelayanan dan kunjungan masa nifas. Di Indonesia, Buku KIA merupakan buku pegangan dalam memberikan informasi kesehatan pada masa nifas yang merupakan salah satu strategi pemerintah dalam upaya pemberdayaan kesehatan khususnya keluarga untuk memlihara kesehatan dan mendapatkan pelayanan kesehatan ibu dan anak yang berkualitas sehingga dapat meningkatkanpengetahuan dan keterampilan keluarga.

Buku KIA terdiri dari informasi dan materi penyuluhan tentang gizi dan kesehatan ibu dan anak, perawatan sehari-hari tentang ibu hamil, bersalin dan Nifas. Berdasarkan hasil penelitian pemanfaatan Buku KIA oleh Ibu nifas diperoleh hasil masih banyak ibu yang belum pernah membaca setiap bagian buku KIA dan yang membaca masih menyatakan kesulitan untuk memahami buku KIA tersebut. Oleh karena itu diperlukan pengembangan media pemberian informasi yang lebih optimal.

Pada minggu pertama masa nifas setidaknya dilaporkan satu masalah terjadi dan mayoritas dapat diselesaikan melalui peningkatan kesadaran dan pendidikan kesehatan.Dalam meningkatkan kesejahteraan dan kesehatan Ibu, pendidikan kesehatan dianggap sebagai salah satu strategi dasar yang paling banyak digunakan untuk meningkatkan kesehatan dan promosi kualitas hidup. Penggunaan sistem informasi kesehatan dapat diterapkan dalam melakukan promosi kesehatan.Salah satu media promosi yang dapat digunakan yaitu media elektronik, melalui penggunaan smartphone.

Perkembangan teknologi informasi yang pesat memungkinkan dapat membantu dalam peningkatan kesehatan dan peningkatan kualitas penyampaian informasi kepada masyarakat kesehatan serta memberikan pendidikan kesehatan dan perubahan perilaku seseorang kearah yang baik. Penggunaan aplikasi $m$-health sebagai media promosi kesehatan dapat memengaruhi pengetahuan dan keterampilan seseorang.

Data pengguna aktif smartphone di Indonesia pada tahun 2019, meningkat mencapai 100 juta pengguna (Suparwedi, 2018). Smart phone dibangun oleh sistem operasi, android, IOS, Blackberry dan windows. Smartphone yang paling banyak digunakan di dunia dan di Indonesia adalah android. Di Indonesia jumlah 
pengguna internet sebesar $64,8 \%$ dan menggunakan internet untuk menginstal aplikasi. Aplikasi yang diinstal diantaranya yaitu aplikasi kesehatan. Smartphone memiliki kelebihan dibandingkan dengan media konvensional diantaranya yaitu tidak mudah rusak, mudah dibawa, dapat digunakan disemua tempat, tanpa keterbatasan waktu, dan aplikasinya berbentuk animasi yang menarik, sehingga Smartphone paling diminati penggunaanya.

Hasil studi pendahuluan yang dilakukan di wilayah kerja Puskesmas Gadingrejo, peneliti melakukan wawancara pada ibu nifas, dari 15 responden ibu nifas didapatkan hasil bahwa $87 \%$ responden ibu nifas memiliki smartphone dan dapat menggunakan smartphone dengan baik. Untuk memenuhi kurangnya informasi kesehatan yang diperoleh dari tenaga kesehatan, responden memilih menggunakan smartphone. Hasil penelitian menyatakan bahwa kebanyakan ibu setelah melahirkan mencari informasi tentang teknik menyusui dan perkembangan bayi melalui aplikasi pada smartphone mereka. Hal ini menunjukkan bahwa responden juga akan mengakses informasi perawatan nifas lainya melalui smartphone.

Selain itu dari 15 responden ibu nifas didapatkan sebanyak $40 \%$ responden ibu nifas mengatakan tidak memahami tentang teknik menyusui yang benar, $33 \%$ tidak memahami perawatan payudara dan $27 \%$ responden $\mathrm{ibu}$ nifas tidak memahami dengan baik perawatan vulva hygiene. Kurangnya pengetahuan tentang perawatan nifas disebabkan karena ibu memperoleh informasi yang terbatas tentang perawatan masa nifas. Pengetahuan ibu yang kurang baik ini dapat diatasi dengan pemberian informasi mengenai perawatan nifas melalui penggunaan smartphone.

Dalam mengembangkan aplikasi ini, peneliti melakukan kolaborasi dengan tim ahli bidang Informasi dan Teknologi (IT) untuk membuat aplikasi mommy nifas, mengenai perawatan masa nifas yang didasarkan pada kebutuhan ibu. Aplikasi ini memiliki keunggulan yaitu terdapat akses untuk berkomunikasi dengan tenaga kesehatan (Bidan), mudah dioperasikan, didesain secara edukatif dan menarik dalam penggunaan gambar dan warna sehingga ibu mau membaca dan mengaplikasikannya dirumah. Penelitian ini ingin melihat pengaruh penggunaan aplikasi mommy nifas terhadappeningkatan pengetahuan dan keterampilan ibu mengenai perawatan masa nifas.

\section{METODE}

Penelitian ini menggunakan rancangan quasi experiment dengan pre-post-test with control group design. Subjek penelitian yaitu ibu nifas di wilayah kerja peskesmas gadingrejo pada bulan september sampai dengan oktober tahun 2019 sebanyak 60 responden, terdiri dari 30 responden kelompok perlakuan dan 30 kelompok kontrol dengan teknik consecutive sampling. Kelompok intervensi yaitu ibu yang mendapatkan aplikasi mommy nifas dan kelompok kontrol yaitu ibu yang tidak mendapatkan aplikasi mommy nifas.

Pengumpulan data tentang perawatan masa nifas menggunakan data primer. Instrumen pengumpulan data berbentuk kuesioner dan daftar tilik. Kuesioner ini diberikan pada saat pre dan post yang bertujuan untuk mengukur pengetahuan dan daftar tilik digunakan untuk mengukur keterampilan ibu nifas tentang perawatan ibu nifas terdiri dari perawatan payudara, teknik menyusui, vulvahygiene dan perineum, senam nifas.

Pengumpulan data diawali dengan memberikan penjelasan mengenai prosedur pelaksanaan penelitian kepada responden dan responden yang bersedia berpartisipasi dalam penelitian menandatangi lembar persetujuan. Peneliti memberikan pre test pada kedua kelompok menggunakan kuesioner dan daftar tilik. Selanjutnya pada kelompok perlakuan peneliti menjelaskan penggunaan aplikasi mommy nifas dengan terlebih dahulu memberikan informasi mengenai perawatan nifas dan menganjurkan responden membuka link atau mengunduh aplikasi mommy nifas, sedangkan pada kelompok kontrol peneliti memberikan informasi mengenai perawatan nifas. Post test pada kedua kelompok dilakukan setelah dua minggu perlakuan. Analisis data menggunakan uji chi kuadrat untuk melihat pengaruh aplikasi terhadap peningkatan pengetahuan dan keterampilan ibu tentang perawatan masa nifas.

Penelitian ini telah mendapatkan persetujuan etik (ethical approval) dari komisi etik penelitian Universitas Padjajaran dengan nomor 1127/UN6.KEP/EC/2019. 
HASIL

Tabel 1. Karakteristik Ibu Nifas pada Kelompok Intervensi dan Kelompok Kontrol

\begin{tabular}{lrrr}
\hline \multirow{2}{*}{ Karakteristik } & \multicolumn{2}{c}{ Kelompok } & \\
\cline { 2 - 4 } Umur & \multicolumn{1}{c}{ Intervensi } & Kontrol & \\
< 20 Tahun & $1(3,3 \%)$ & $1(3,3 \%)$ & 0,553 \\
20-35 Tahun & $23(76,7 \%)$ & $26(86,7 \%)$ & \\
>35 Tahun & $6(20 \%)$ & $3(10 \%)$ & \\
Pendidikan & & & \\
Dasar (SD/SMP) & $12(40 \%)$ & $10(33,3 \%)$ & 0,545 \\
Menengah (SMA) & $13(43,3 \%)$ & $17(56,7 \%)$ & \\
Tinggi (PT) & $5(16,7 \%)$ & $3(10 \%)$ & \\
Paritas & $12(40 \%)$ & $14(46,7 \%)$ & 0,602 \\
Primipara & $18(60 \%)$ & $16(53,3 \%)$ & \\
Multipara & & & \\
\hline
\end{tabular}

Berdasarkan tabel 1, terlihat bahwa karakteristik responden yang meliputi umur, pendidikan, dan paritas pada kedua kelompok penelitian menunjukkan tidak adanya perbedaan ( $p$-value $>0,05)$. Hal ini menunjukkan bahwa kedua kelompok homogen sehingga layak untuk dibandingkan.

Tabel 2. Perbedaan Skor Pengetahuan dan Keterampilan Pada Kelompok Intervensi dan Kontrol (Pre dan Post)

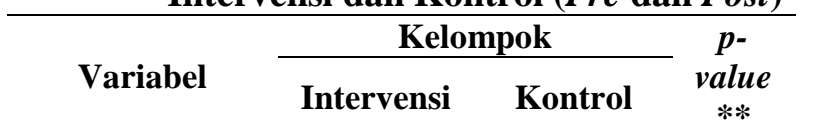

\begin{tabular}{|c|c|c|c|}
\hline \multicolumn{4}{|l|}{ Pengetahuan } \\
\hline a. Data pre & & & \multirow{3}{*}{0,003} \\
\hline $\mathrm{x}(\mathrm{SD})$ & $71,3(8,7)$ & $65,03(3,7)$ & \\
\hline Median & 71,5 & 66 & \\
\hline Rentang & $53-86$ & $60-73$ & \\
\hline \multicolumn{4}{|l|}{ b. Data post } \\
\hline $\mathrm{x}(\mathrm{SD})$ & $87,2(8.8)$ & $69,9(8,9)$ & \multirow{3}{*}{0,001} \\
\hline Median & 93 & 70 & \\
\hline Rentang & 70-96 & $56-83$ & \\
\hline $\begin{array}{l}\text { Perbandingan } \\
\text { pre dan post }\end{array}$ & $p^{*<0,001}$ & $p^{*}<0,002$ & \\
\hline $\begin{array}{l}\text { \%Peningkatan } \\
\text { pengetahuan }\end{array}$ & $17 \%$ & $7,8 \%$ & $<0,001$ \\
\hline \multicolumn{4}{|l|}{ Keterampilan } \\
\hline $\begin{array}{l}\text { a. Data pre } \\
\mathrm{x}(\mathrm{SD})\end{array}$ & $50,8(5,7)$ & $49,9(7,3)$ & \multirow[t]{2}{*}{0,512} \\
\hline Median & 50 & 50 & \\
\hline Rentang & $40-60$ & $38-69$ & \\
\hline \multicolumn{3}{|l|}{ b. Data post } & \multirow{3}{*}{0,001} \\
\hline Median & 70,5 & 50 & \\
\hline Rentang & $61-83$ & $33-75$ & \\
\hline $\begin{array}{l}\text { Perbandingan } \\
\text { pre dan post }\end{array}$ & $p^{*}<0,001$ & $p^{*}=0,050$ & \\
\hline $\begin{array}{l}\text { \% Peningkatan } \\
\text { keterampilan }\end{array}$ & $40 \%$ & $0 \%$ & 0,001 \\
\hline
\end{tabular}

Berdasarkan tabel 2 terlihat bahwa terdapat perbedaan skor pengetahuan sebelum dilakukan intervensi $\quad(p$-value $<0,05), \quad$ sehingga pada pengetahuan akan dilihat berdasarkan persentase kenaikan pengetahuan pada kedua kelompok setelah dilakukan intervensi. Hasil kenaikan pengetahuan pada kelompok perlakuan sebesar $17 \%$ dan pada kelompok kontrol persentase kenaikan sebesar 7,8\%. Hal ini menunjukkan terdapat peningkatan persentase kenaikan pengetahuan pada kelompok perlakuan lebih besar dari pada kelompok kontrol.

Pada keterampilan tidak terdapat perbedaan skor keterampilan sebelum dilakukan intervensi ( $p$-value>0,05). Peningkatan skor keterampilan pada kedua kelompok setelah dilakukan intervensi terlihat bahwa pada kelompok perlakukan terdapat kenaikan keterampilan sebesar $40 \%$, sedangkan pada kelompok kontrol tidak terdapat persentase kenaikan keterampilan (0\%). Hal ini menunjukkan terdapat peningkatan persentase kenaikan keterampilan pada kelompok perlakuan lebih besar dari pada kelompok kontrol. Selain itu terdapat perbedaan yang bermakna antara kelompok perlakuan (diberikan aplikasi) dan kelompok kontrol baik dari segi pengetahuan dan keterampilan dengan nilai $p$-value $<0,05$.

\begin{tabular}{|c|c|c|c|}
\hline Tabel 3. Per & & getahuan & $\begin{array}{r}\text { dan } \\
\text { domnok }\end{array}$ \\
\hline $\begin{array}{l}\text { Kete } \\
\text { Inte } \\
\text { Pos }\end{array}$ & $\begin{array}{l}\text { npilan } \\
\text { osi dan } \\
\text { t) }\end{array}$ & $\begin{array}{l}\text { ada } \\
\text { elompok }\end{array}$ & $\begin{array}{l}\text { lompok } \\
\text { Kontrol }\end{array}$ \\
\hline & Kelo & pok & \\
\hline Variabel & Intervensi & Kontrol & \\
\hline Pengetahuan & & & \\
\hline Baik & $24(80 \%)$ & $11(36,7 \%)$ & 0,001 \\
\hline Tidak Baik & $6(20 \%)$ & $19(63,3 \%)$ & \\
\hline Keterampilar & & & \\
\hline Mahi & $26(86,7 \%)$ & $5(16,7 \%)$ & 0,001 \\
\hline Tidak Mahir & $4(13,3 \%)$ & $25(83,3 \%)$ & \\
\hline
\end{tabular}


Berdasarkan tabel 3 didapatkan hasil bahwa pada kelompok perlakuan terdapat 24 $(80 \%)$ responden dari 30 responden yang mengalami peningkatan pengetahuan yang baik. Sedangkan pada kelompok kontrol hanya 11 $(36,7 \%)$ responden yang mengalami peningkatan pengetahuan yang baik. Pada variabel keterampilan, kelompok perlakuan mengalami peningkatan keterampilan yang mahir yaitu 26 $(86,7 \%)$ responden dari 30 responden yang mengalami peningkatan keterampilan yang mahir, sedangkan pada kelompok kontrol hanya 5 $(16,7 \%)$ yang mengalami peningkatan keterampilan yang mahir tentang perawatan masa nifas (perawatan payudara, vulva hygiene, teknik menyusui dan senam). Secara statistik menunjukkan bahwa terdapat perbedaan bermakna antara kelompok perlakuan dan kelompok kontrol untuk variabel pengetahuan dan keterampilan $(p$-value $<0,05)$.

Dari tabel 3 dapat dihitung besarnya pengaruh penggunaan aplikasi mommy nifas terhadap peningkatan pengetahuan dan keterampilan yang dapat dilihat pada tabel 4 dibawah ini:

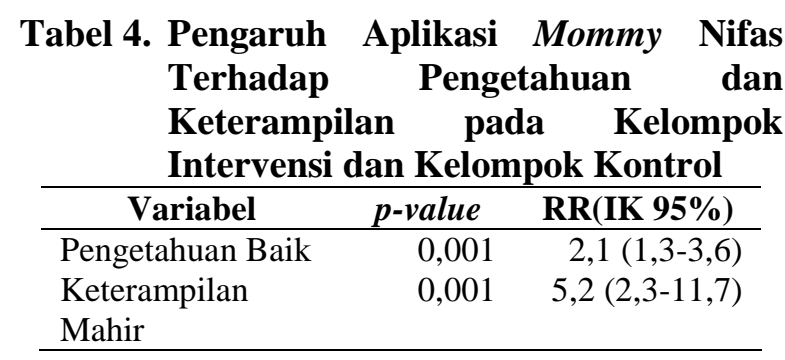

Berdasarkan tabel 4 terlihat bahwa terdapat pengaruh penggunaan aplikasi mommy nifas terhadap peningkatan pengetahuan yang baik dan peningkatan keterampilan yang mahir. Hasil Uji statistik menggunakan chi kuadrat menunjukkan pada variabel pengetahuan yang baik didapatkan nilai $p$-value $=0,001$, dan RR 2,1 , IK 95\%. Hal ini menunjukkan bahwa pada kelompok yang diberikan aplikasi mommy nifas berpeluang terjadi peningkatan pengetahuan yang baik 2,1 kali tentang perawatan masa nifas dibandingkan dengan kelompok kontrol. Pada variabel keterampilan yang mahir didapatkan nilai $p$ value $=0,001$, dan RR 5,2, IK 95\%, hal ini berarti pada kelompok yang diberikan aplikasi mommy nifas berpeluang terjadi peningkatan keterampilan yang mahir 5,2 kali dibandingkan kelompok kontrol dalam melakukan perawatan nifas yang terdiri dari perawatan payudara, vulva hygiene, teknik menyusui dan senam nifas.

\section{PEMBAHASAN}

Hasil penelitian menunjukan bahwa usia rsponden sebagian besar usia produktif. Umur individu yang dihitung mulai saat dilahirkan sampai berulang tahun. Usia mempengaruhi daya tangkap dan pola pikir seseorang. Semakin bertambahnya usia akan semakin berkembang pula daya tangkap dan pola pikirnya sehingga pengetahuan yang diperolehnya semakin membaik. Umumnya umur lebih tua cenderung mempunyai pengalaman, sehingga umur yang lebih tua mempunyai kemandirian dalam melakukan perawatan diri dalam masa nifas.

Mayoritas pendidikan responden berada pada tingkat menengah Proses pemberian informasi kesehatan melalui pemberian pendidikan kesehatan yang terus menerus dan berkesinambungan bertujuan untuk memberikan pengetahuan dan pemahaman tentang kesehatan, pemahaman dan penerimaan informasi seseorang berkaitan dengan tingkat pendidikan hal ini berarti semakin tinggi pendidikan seseorang maka semakin mudah dan banyak pengetahuan yang dimiliki. Selain itu pendidikan dikaitkan juga dengan perilaku yang diperlihatkan oleh seseorang berasal dari pengetahuan yang didapatkan. Ibu yang memiliki pengetahuan menengah diharapkan sudah memiliki pengetahuan yang lebih banyak tentang perawatan diri sehingga ibu mau melakukan perawatan diri ada masa nifas.

Paritas responden pada kedua kelompok mayoritas terdiri dari mulriparitas atau ibu yang telah memiliki anak lebih dari satu. Paritas merupakan jumlah anak yang dilahirkan oleh seorang ibu baik lahir hidup maupun lahir mati. Pada dasarnya pengetahuan akan bertambah dan bervariasi sesuai dengan pengalaman yang dialami oleh seseorang. Paritas dapat dikaitkan dengan pengalaman, pengalaman memberikan pengaruh pada perilaku ibu untuk melakukan perawatan diri masa nifas.

\section{Pengaruh Penggunaan Aplikasi Mommy Nifas terhadap Peningkatan Pengetahuan dan Keterampilan}

Berdasarkan tabel.2 terlihat ada perbedaan yang bermakna antara kelompok perlakuan dan kelompok kontrol pada skor pengetahuan setelah dilakukan intervensi. Hasil uji statistik dengan uji chi-square menunjukkan terdapat perbedaan peningkatan pengetahuan yang bermakna antara kelompok perlakuan dan kelompok kontrol. Jumlah peningkatan pengetahuan pada kelompok intervensi. . 
Selain itu pada tabel 4 menunjukkan terdapat pengaruh penggunaan aplikasi moomy nifas pada kelompok perlakuan. Kelompok yang diberikan aplikasi (kelompok perlakuan) berpeluang 2,1 kali memiliki pengetahuan yang baik tentang perawatan masa nifas dibandingkan dengan kelompok kontrol.

Pengetahuan adalah hasil dari penginderaan manusia, atau hasil tahu seseorang terhadap objek melalui indra (mata, hidung, telinga dan sebagainya) yang dimilikinya. Pada waktu pengindraan sampai menghasilkan pengetahuan tersebut sangat dipengaruhi oleh intensitas dan persepsi terhadap objek. Sebagian besar pengetahuan seseorang diperoleh melalui indra pendengaran yaitu telinga dan indera penglihatan yaitu mata. Penerimaan informasi merupakan suatu proses untuk menciptakan pengetahuan, sikap dan keterampilan. Hal ini diperoleh secara bertahap yang menyebabkan seseorang mengadopsi informasi baru yang diterimanya. Pengetahuan atau kognitif merupakan domain yang sangat penting dalam membentuk tindakan seseorang (over behaviour).

Perawatan masa nifas merupakan perawatan yang khusus diberikan kepada ibu setelah melahirkan sampai alat-alat kandungan kembali seperti sebelum hamil, lamanya kira-kira 6-8 minggu.Perawatan diri pada masa nifas diperlukan karena wanita banyak mengalami perubahan pada dirinya baik fisik maupun psikologis.Pada masa ini merupakan masa pemulihan yang sangat penting bagi wanita, sehingga diharapkan wanita dapat melakukan perawatan untuk dirinya sehingga tidak mengalami gangguan kesehatan.Pendidikan kesehatan merupakan salah satu cara pemberian informasi yang dapat meningkatkan pendidikan seseorang.

Dalam penelitian ini terdapat pengaruh penggunaan aplikasi mommy nifas terhadap peningkatan pengetahuan ibu tentang perawatan nifas. Hal ini menunjukkan bahwa pengetahuan ibu meningkat setelah mendapatkan pendidikan kesehatan melalui aplikasi mommy nifas. Hasil penelitian ini sejalan dengan Nuryati, et al. (2017) penggunakan aplikasi media sosial dapat meningkatkan pengetahuan ibu tentang perawatan nifas. Melalui smartphone pesan yang disampaikan cepat dan nyata dalam menimbulkan rangsangan untuk diikuti sehingga pemahaman seseorang lebih komprehensif. Hal ini juga didukung oleh Herlina, et al. (2013) menjelaskan bahwa penggunaan aplikasi smartphone efektif digunakan sebagai media untuk menyampaikan informasi sehingga meningkatkan pengetahuan ibu
Penggunaan media dalam pemberian informasi dapat mengerahkan indera sebanyak mungkin terhadap suatu objek sehingga mempermudah memperoleh informasi yang dianggap rumit menjadi mudah. Salah satu media promosi yang dapat digunakan yaitu media elektronik,melalui penggunaan smartphone. Smartphone memiliki kelebihan dibandingkan dengan media konvensional diantaranya yaitu tidak mudah rusak, mudah dibawa, dapat digunakan disemua tempat, tanpa keterbatasan waktu, dan aplikasinya berbentuk animasi yang menarik, sehingga Smartphone paling diminati penggunaanya.

Selain memengaruhi pengetahuan aplikasi mommy nifas juga mempengaruhi keterampilan ibu nifas dalam melakukan perawatan masa nifas. Berdasarkan hasil penelitian pada tabel 2 didapatkan bahwa ada perbedaan yang bermakna antara kelompok perlakuan dan kelompok kontrol pada skor keterampilan setelah dilakukan intervensi. Hasil uji statistik dengan uji chi square terdapat perbedaan peningkatan keterampilan yang bermakna antara kelompok perlakuan dan kelompok kontrol. Terdapat peningkatan keterampilan pada kelompok perlakuan sedangkan pada kelompok kontrol tidak terdapat peningkatan keterampilan. Selain itu, berdasarkan tabel 4 menggunakan uji statistic chi square test menunjukkan bahwa kelompok yang diberikan aplikasi (kelompok perlakuan) berpeluang terjadi peningkatan keterampilan yang mahir 5,2 kali dibandingkan kelompok kontrol dalam melakukan perawatan masa nifas yang terdiri dari perawatan payudara, vulva hygiene, teknik menyusui dan senam nifas.

Keterampilan dapat diartikan kemampuan melaksanakan tugas melalui penerapan dan pengalaman. Keterampilan dapat juga diartikan sebagai kemampuan seseorang dalam melakukan sesuatu untuk mengubah perilaku menjadi cepat, tepat dan cekatan. Keterampilan yang dilakukan secara berulang-ulang akan menjadikan seseorang menjadi kompeten, ahli, cepat dan kinerja terampil. Kemampuan persepsi, respon motorik dan memecahkan masalah merupakan kombinasi dalam membuat kinerja menjadi terampil.

Hasil penelitian didapatkan bahwa terdapat pengaruh penggunaan aplikasi mommy nifas terhadap keterampilan ibu dalam melakukan perawatan nifas. Hal ini sejalan dengan penelitian yang dilakukan oleh Out, et al. (2016) menyatakan bahwa penggunaan aplikasi mhealth sebagai media promosi kesehatan dapat memengaruhi pengetahuan dan keterampilan seseorang. Nasution dan Hariyati (2018) 
Implementasi penggunaan "mobile health" pada pelayanan keperawatan maternitas menunjukkan dampak yang positif terhadap pengetahuan, motivasi, dan perilaku kesehatan ibu. Selain itu didukung pula oleh Labrique, et al. (2013) yang menyatakan bahwa salah satu fungsi dari penggunaan $m$ - health adalah memberikan pendidikan kesehatan untuk perubahan perilaku seseorang kearah yang baik.

Penelitian yang dilakukan oleh Asiodu, et al. (2015) didapatkan bahwa sebagian besar ibu nifas mencariinformasi tentang teknik menyusui danperkembangan bayi melalui aplikasi dismartphone.Salah satu fungsi dari penggunaan mobile health adalah memberikan pendidikan kesehatan dan perubahan perilaku kesehatan. $M$ health dapat meningkatkan pengetahuan, mempengaruhi sikap dan mengubah perilaku pasien terhadap kesehatanya, sehingga dapat meningkatkan status kesehatan mereka.Hal ini sejalan dengan penelitian yang dilakukan oleh Shiferaw, et al. (2016) pemanfaatan m-health pada masa pasca kelahiran dapat meningkatkan kualitas perawatan ibudan memotivasi dia untuk memeriksanya secara rutinsituasi ke fasilitas layanan kesehatan terdekat.

Pada penelitian ini peningkatan pengetahuan dan keterampilan mengenai perawatan nifas, diperoleh pada responden yang menggunakan aplikasi mommy nifas. Responden sebagian besar merupakan ibu dengan umur yang masih produktif dan aktif dalam mencari informasi. Pendidikan berada pada tingkat menengah dan mayoritas resonden memiliki anak lebih dari satu. Hal ini menunjukkan bahwa responden memiliki pengetahuan serta pengalaman yang lebih banyak tentang perawatan diri pada masa nifas.

Pemanfaatan aplikasi mommy nifas yang digunakan setiap hari oleh ibu dapat menambah memori jangka panjang tentang perawatan masa nifas dan membuat ibu membiasakan diri melakukan dan mengulang keterampilan perawatan masa nifas (perawatan payudara, vulva hygiene, teknik menyusui dan senam nifas) sehingga ibu menjadi mahir. Selain itu data Asosiasi Penyedia Jasa Internet Indonesia (APJII) (2015) didapatkan bahwa di Indonesia pemanfaatan internet melalui penggunaan smartphone di dominasi oleh perempuan, usia aktif, pendidikan menengah/pendidikan tinggi, lama mengakses internet paling banyak 180 menit perhari.

Penggunaan media cetak seperti Buku KIA memiliki keterbatasan diantaranya informasi mengenai perawatan nifas terbatas, tdak dapat digunakan kapanpun, buku mudah hilang dan rusak serta tidak memungkinkan untuk berinteraksi langsung dengan bidan. Hal ini sejalan dengan hasil studi Sistiarani, et al. (2014) bahwa dalam pemanfaatan buku KIA masih terdapat ibu yang belum pernah membaca atau telah membaca dan masih menemui kesulitan dalam memahami. Oleh karena itu aplikasi mommy nifas ini dirancang untuk mengatasi keterbatasan tersebut.

Aplikasi mommy nifas ini dapat memberikan informasi tambahan tentang perawatan nifas, dapat diakses dengan mudah, menggunakan bahasa yang mudah dimengerti serta dilengkapi dengan gambar ilustrasi dan terdapat menu interaksi dengan bidan. Aplikasi ini diharapkan dapat menjadi salah satu media tambahan oleh tenaga kesehatan khususnya bidan dalam memberikan pendidikan kesehatan mengenai perawatan nifas sehingga pengetahuan ibu nifas meningkat yang berdampak pada terampilnya ibu dalam melakukan perawatan nifas dirumah secara mandiri.

\section{SIMPULAN}

Berdasarkan hasil penelitian dan pembahasan dapat disimpulkan bahwa peningkatan persentase pengetahuan tentang perawatan nifas pada kelompok perlakuan lebih besar dari kelompok kontrol setelah diberikan aplikasi mommy nifas dan penggunaan aplikasi mommy nifas berpengaruh terhadap peningkatan keterampilan ibu dalam melakukan perawatan nifas.

Aplikasi mommy nifas dapat dijadikan sebagai salah satu media tambahan oleh tenaga kesehatan khususnya bidan dalam melakukan pendidikan kesehatan sehingga dapat meningkatkan pengetahuan dan keterampilan ibu dalam melakukan perawatan nifas.

\section{DAFTAR PUSTAKA}

APJII. (2015). Profil Pengguna Internet Tahun 2014. Jakarta: Puskakom UI.

Asiodu, I. V., Waters, C. M., Dailey, D. E., Lee, K. A., \& Lyndon, A. (2015). Breastfeeding and use of social media among first-time African American mothers. Journal of Obstetric, Gynecologic \& Neonatal Nursing, 44(2), 268-278. 
Dewi, Y. V. A. (2020). Buku Ajar Asuhan Kebidanan 3. Media Sains Indonesia.

Herlina, S, Sanjaya GY, Emilia O. (2013). Pemanfaatan SMS Telepon Seluler Sebagai Media Ibu Hamil Di Daerah Terpensil. Seminar Nasional Sistem Informasi Indonesia.

Kementerian Kesehatan RI. (2014). Menteri Kesehatan RI. Pelayanan Kesehatan Masa Sebelum Hamil, Masa Hamil, Persalinan, Dan Masa Sesudah Melahirkan, Penyelenggaraan Pelayanan Kontrasepsi, Serta Pelayanan Kesehatan Seksual Peraturan Menteri Kesehatan Nomor 97 Tahun 2014. Jakarta.

Labrique, A. B., Vasudevan, L., Kochi, E., Fabricant, R., \& Mehl, G. (2013). mHealth innovations as health system strengthening tools: 12 common applications and a visual framework. Global health: science and practice, 1(2), 160-171.

Nasution, L. A., \& Hariyati, R. T. S. (2018). Mobile health application in implementation of maternity nursing care: literature review. Journal of Nursing Care, 1(1), 34-41.

Nuryati, Sinta. (2017). Efektifitas Penggunaan Media Sosial Terhadap Peningkatan Pengetahuan Perawatan Masa Nifas Dan Kepatuhan Kunjungan Ulang Pada Ibu Nifas Di Kota Bogor. Midwifery Journal. $3(1)$.

Out A, Ebenso B, OKUZU O, Osifo-dawodu E. (2016). Using A M Health Tutorial
Application To Change Knoeledge And Attitude Of Frontline Health Workers To Ebola Virus Disease In Nigeria:A BeforeAnd-After Dtusy. Hum Resour Health.14(5),1-9.

Rachmawati, I. N., Allenidekania, A., \& Wijayarini, M. A. (2001). Identifikasi Kebutuhan Perawatan Mandiri Ibu Nifas. Jurnal Keperawatan Indonesia, 5(2), 60-66.

Sagita Eldawati. (2015). Hubungan Pengetahuan Dan Sikap Ibu Nifas Dengan Praktik Perawatan Masa Nifas Di Kecamatan Gunung pati Kota Semarang. Jurnal Kesmas. 3(3).

Shiferaw, S., Spigt, M., Tekie, M., Abdullah, M., Fantahun, M., \& Dinant, G. J. (2016). The effects of a locally developed mHealth intervention on delivery and postnatal care utilization; a prospective controlled evaluation among health centres in Ethiopia. PloS one, 11(7), e0158600.

Sistiarani, C. (2014). Analisis kualitas penggunaan buku kesehatan ibu anak. KEMAS: Jurnal Kesehatan Masyarakat, 10(1), 14-20.

Suparwedi, W. (2018). Data Pengguna Aktif Smartphone di Indonesia. Harian Ekonomi Neraca. http://www.neraca.co.id/article/98769/.

Wiegers, TA. (2006). Maternity Care Assistance During The Postpartum Period: How To Help New Mothers Cope. Journal of Neonatal Nursing, 12(5), 163-171. 